\title{
It's Very Different Here: Practice-Based Academic Staff Induction and Retention
}

\section{Virginia King}

Centre for Global Learning: Education and Attainment, Coventry University, Coventry, United Kingdom

Jannie Roed

The ExPERT Academy, University of West London, London, United Kingdom

Louise Wilson

Organisation Development and Academic Development, Coventry University, Coventry, United Kingdom

Corresponding Author:

Dr Virginia King, Centre for Global Learning: Education and Attainment, Coventry University, Priory Street, Coventry, CV1 5FB, United Kingdom

Telephone: +44 (0)24 76715989

ORCID: https://orcid.org/0000-0003-2090-7382

Email: v.c.king@ coventry.ac.uk

Co-author contact details:

Dr Jannie Roed, ExPERT Academy, University of West London, St Mary's Road Ealing, London W5 5RF, United Kingdom

Telephone: +44 (0)20 82312690

Email: Jannie.Roed@uwl.ac.uk

Louise Wilson, Organisation Development and Academic Development, Coventry University, Priory Street, Coventry, CV1 5FB, United Kingdom

Telephone: +44 (0)24 76655108

Email: louise.wilson@ coventry.ac.uk

\section{Citation:}

King, V. C., Roed, J., and Wilson, L. (In Press, 2018) It's Very Different Here: PracticeBased Academic Staff Induction and Retention. Journal of Higher Education Policy and Management. 


\title{
It's Very Different Here: Practice-Based Academic Staff Induction and Retention
}

\begin{abstract}
The sociologist, Max Weber (1864-1920), suggested that few could withstand the frustrations of academic life. As the strategic management of human resources begins to differentiate higher education institutions (HEIs) in league tables, the costs of voluntary staff turnover (attrition) become more significant. In this paper, we consider links between induction (orientation) and retention for academic staff. We report on a qualitative study of thirty academic staff in five United Kingdom HEIs who were recruited on the basis of their professional experience. Their practice-based knowledge lends our participants particular insight into their HEI induction experience which, where found wanting, led in several cases to resignation. We analyse the induction experiences of our participants to glean explanations for these perceived shortcomings. Since induction interventions are thought to lead to improved retention, we recommend policy and practice changes to induction which may benefit all academic staff.
\end{abstract}

Keywords: academic staff; faculty; onboarding; orientation; retention; turnover

\section{Introduction}

Academic life is not for everyone. A century ago, the sociologist, Max Weber (18641920), considered the appeal and challenges of the academic vocation, and concluded that few could withstand the frustrations of academic life (Weber, 1948 [1919]). Weber argued that, despite different organisational structures, the academic role in different countries demanded the same excellence as teacher, researcher and communicator; ability to satisfy the competing expectations of students and superiors; commitment to one's chosen discipline; readiness to compete for recognition; and ability to withstand repeated disappointment. Many of today's academics will recognise this 'person specification' - though few could realistically claim to meet it - and most still survive in this challenging environment. However, some academics find the demands they encounter to be unexpected or excessive, and they choose to leave (Bucklin, Valley, Welch, Tran, \& Lowenstein, 2014; O'Meara, Lounder, \& Campbell, 2014).

In this paper, our aim is to highlight the impact on the individual of higher education institution (HEI) induction policy implementation - so that the reader may compare it with their own HE context (Denscombe, 2014). Against the background of academic recruitment and induction (orientation) in general, we explore the experiences of a sample taken from one sub-group of United Kingdom academics: those recruited into the academy from other professions. Their external insights highlight issues which may affect academic staff retention more generally. Since human resources (HR) 
induction interventions are thought to lead to improved retention and performance, we end by recommending the application of lessons learnt to the policy and practice of induction for all academic staff.

\section{Academic staff induction and retention}

\section{Induction}

Academic induction is one of the processes which enable recruits to understand and perform their role within an HEI. According to Mullins, (2005, p. 816), '[i]nduction should include attention to rules and regulations, familiarisation with the culture and methods of operation of the organisation, and personal training and development needs'. This may be achieved through training courses, mentorship or programmed activity, or combinations of these. There is no standard approach nationally or internationally, but, where formalised, HEIs usually rely on generic staff induction plans designed by their HR departments, supplemented by academic development arrangements which normally focus on teaching and research skills acquisition. The formal induction process will cover a probationary period (which in the UK, alone, can vary from one to four years [Smith, 2010]). In this paper, we use the term 'induction' to encompass the early career stage which can last up to five years (Price, Coffey, \& Nethery, 2015).

Reports of successful academic staff induction are notably scarce, one exception being Meizlish, Wright, Howard, and Kaplan (2017). A major issue with academic induction identified in the literature is a widespread failure to recognise the individual needs of recruits, be they post-doctoral students, professionals transferring from a nonacademic career, international recruits, part-time employees, or underrepresented group members. Saltmarsh and Swirski (2010) find that international academics in Australia experienced the induction processes as inadequate, highlighting participants' 'initial struggle with the assumed knowledge upon which induction and professional development activities were reliant' (p. 295). Similarly, Walker's (2015, p. 72) study of international academics in the United Kingdom reports that they felt it was 'the unfamiliar cultural norms and mores that can be challenging' and which they were not supported in resolving. Members of a range of underrepresented groups may struggle to get to grips with assumed norms on entering academia (Dominguez-Whitehead \& Moosa, 2014). Furthermore, as O'Meara, Bennett, and Neihaus (2016) highlight, there 
may be a mismatch in expectations between recruits and the HEI which the induction process seems not to resolve.

The second key issue we identified concerns perceived deficiencies in the management support provided to new recruits to ensure their swift and efficient integration into their new roles while taking account of their personal circumstances. An example of the effect of a perceived lack of support is given by Gourlay (2011) of a UK academic who had been recruited from clinical practice and felt invisible and isolated 'in contrast to a strong emphasis on teamwork, 'emotional literacy' and care in the clinical setting' (p. 592).

The effective management of 'human capital' is increasingly seen as the key element in organisational performance. That is, it is not enough to attract and recruit the right staff, they must be retained; and their individual skills, knowledge and abilities must be leveraged (Ketchen Jr., Crook, Todd, Combs, \& Woehr, 2017). This suggests that understanding the expectations and potential of individual staff, and supporting them in finding the best opportunities to contribute, are essential aspects of induction that underpin performance and retention.

\section{Retention}

Staff retention is a strategic issue (Ketchen Jr. et al., 2017). According to Schloss, Flanagan, Culler, and Wright (2009), Bucklin et al. (2014), and Allen (2006), the cost to an HEI of academic staff turnover can include advertising a post; shortlisting; interviewing and selecting candidates; training, orienting and supporting the new recruit; probation processes; covering their role as they leave; as well as loss of income from associated grants or consultancy. For example, Schloss et al. (2009) calculate the average cost in their US medical school 'for replacing a single faculty member being more than $\$ 400,000$ ' (p. 32). There are potential additional reputational costs related to league table positions that may be influenced by staff turnover, including student performance, satisfaction, and retention metrics; as well as staff performance metrics (Welch, 2016). Although academic staff satisfaction and retention metrics are barely beginning to gain external significance (Hazelkorn, 2015), some HEIs aspire to be ranked in tables such as the UK Times Best Employer Table (thesundaytimes.co.uk/best100companies) which take these factors into account (Maxwell \& Farquharson, 2008). At the time of writing, one HEI already featured in that table (University of Sheffield, 2017). 
The national and international exchange of academic staff between HEIs is recognised as fundamental to the health of the academy, providing the means to develop expertise within disciplines. Resignation by academic staff (also called 'voluntary turnover') can be viewed positively by HEIs (since it provides the opportunity to invigorate departments) or may be disregarded since relatively low numbers of staff are involved (Staniforth \& Harland, 2006). For example, in the UK, the Universities and Colleges Employers Association (UCEA, 2017, p. 4) report that:

\footnotetext{
Employee turnover has been rising steadily since 2012 but is still low compared to the wider economy with an overall rate of $8.9 \%$ compared to $18.5 \%$ across the UK. Turnover for professional services staff is higher at $10.4 \%$ and lower for academic staff at $7.9 \%$. In terms of voluntary turnover, the figures are lower still at $6.3 \%$ and $4.4 \%$ respectively compared to $14.1 \%$ in the wider economy.
}

Hidden within these averages, is the much higher turnover of junior academics compared with seniors. For example, UCEA (2017, p. 25) report a turnover rate of 11.2 per cent for Lecturer Grade A compared with 6.2 per cent for professors. Similarly, in one medical faculty, Schloss et al. $(2009$, p. 34) found the turnover rates for assistant professors averaged 10.1 per cent over five years, while that for full professors averaged 2.9 per cent. Turnover is also higher amongst new staff rather than established staff (Allen, 2006), and amongst those with sought-after skills (Robyn \& Du Preez, 2013).

Voluntary turnover may be classified as 'unavoidable' (for example, where it is associated with changes in the individual's family circumstances) or 'avoidable' where it results from employee dissatisfaction (Schloss et al., 2009). However, O'Meara, Lounder, and Campbell (2014) suggest that academic staff may hide their true reasons for leaving an HEI, allowing administrators and managers to imagine either that the individual found themselves inadequate for the demands of their current post, or that they could not resist a superior post elsewhere. The literature suggests that it is often the failure of the academic workplace to meet individuals' expectations, and individuals' perception that their particular needs are not being acknowledged or met, that lie at the heart of academic staff turnover (see, Bucklin et al., 2014; Gourlay, 2011; O'Meara, Bennett, \& Neihaus, 2016; O'Meara, Lounder, \& Campbell, 2014; Robyn \& Du Preez, 2013; Smith, 2010; Watanabe \& Falci, 2016; Wilson, 2013; Yan, Yue, \& Niu, 2015). The role of the line manager is crucial in providing that sense of individualised support, lack of which can be linked to intention to leave (Dominguez-Whitehead \& Moosa, 2014; Robyn \& Du Preez, 2013; Staniforth \& Harland, 2006). 
While there is growing interest in the interplay of factors on academic staff's intention to leave their HEI (e.g. Bentley, Coates, Dobson, Goedegebuure, \& Meek, 2013; Kinman, 2015; Robyn \& Du Preez, 2013; Yan, Yue, \& Niu, 2015), research cannot easily capture the input of those who join and leave an organisation unexpectedly quickly. National statistics (e.g. Australian Government, 2016; Higher Education Statistics Agency [HESA], 2017), monitor the overall inflow and outflow of academic staff but not the duration of their stay. Given the high numbers of short-term contracts in the HE sector, this data would need significant unravelling to expose the full rate of voluntary turnover and non-continuation of contracts. The contribution that induction plays in academic staff retention appears to remain 'unmeasured' (Billot \& King, 2017).

\section{Illustrative study}

\section{Practice-based academic staff}

Our literature review has provided an overview of academic induction internationally which suggests that similar issues may be encountered around the globe. Rather than duplicate these studies, we set out to complement them through a study of individuals who entered the academic profession from other employment sectors. While this limitation makes our sample unrepresentative of the local and global academic workforce, our participants' former professional experience provides useful comparative perspectives on the academic induction process in a range of HEIs.

Boden, Epstein, and Kenway (2005) point out that the increasing demand for vocationally focused degrees means that more staff are likely to make the crossover from professional practice to academia. Such staff members form a key part of teaching teams as they link theory with practice, and help ensure that courses meet student priorities for staff to have 'professional or industry expertise' (HEFCE, 2015, p. 1). Staff who make this crossover will typically have worked in their profession for some years, and developed an expertise in their field, generally within a well-established professional community where their expertise is acknowledged and valued. However, when moving into the academy, they enter a new professional community. Still thinking of themselves as practitioners in a particular field, they may be unaware of the different value system/s awaiting them within HE. Bartunek and Rynes (2014) highlight tensions in practitioner-academic research collaborations, citing differences in their ways of 
communicating and thinking (logics), and in their valuing of time, rigour and relevance. While Bartunek and Rynes (2014) suggest these tensions can enrich collaborative research, they also argue that they can create problems within teams and within individuals who enter academia but who do not see themselves as predominantly academics.

\section{Participants}

We draw on research that set out to explore the transition and socialisation of practicebased academic staff in the academy. Despite being a limitation, the institutions from which our thirty participants were drawn are all sited in the United Kingdom, ensuring contextual consistency.

We employed a mix of purposive sampling and snowball sampling (Denscombe, 2014). At each institution, individuals known to have access to, or responsibility for, early-career academics identified a purposive sample of candidates. Where necessary, additional participants were recruited by asking for recommendations from those already interviewed (snowball sample). Ethical approval for this work was obtained from the relevant HEIs prior to commencement, and the interviewees all gave informed consent permitting anonymised publication of their words. Pseudonyms are used for the participants, and codes (I1-I5) for their institutions.

Our own position is that of managers and developers of academic staff in a range of UK HEIs. Additionally, we have each worked in other professions (commercial IT, business finance, translation services, and teaching).

The study participants had all been appointed within the previous five years. They came from a range of disciplines, and taught subjects within the disciplinary fields related to their professions which included engineering, health, design, business, forensic science, and the performing arts. The majority held full-time, permanent posts, and had undertaken (or were undertaking) an internal post-graduate qualification in teaching and learning recognised and accredited by the UK's Advance HE (formerly the Higher Education Academy). Extreme care has been taken to ensure anonymity, hence our study participants' profile, is simply compared to that of the UK academic workforce as a whole, as set out in Table 1. While generalisability is not our aim, this comparison allows the reader to establish the relevance of our sample to their own context. Table 1 suggests that, other than their academic function (all undertaking both teaching and research), our participants are largely indistinguishable from the norm of 
UK academics. (The other apparent differentiator, holding a teaching qualification, is encouraged by HEFCE [2015] and hence now commonly required in UK universities.)

We were interested to know the extent to which our participants felt different from their peers despite this apparent statistical homogeneity.

Table 1. Characteristics of the interview participants compared with the contemporaneous profile of UK academic workforce

\begin{tabular}{|c|c|c|}
\hline & HESA Data 2015/2016 & $\begin{array}{l}\text { Study participants (at the time of } \\
\text { interview - 2015) }\end{array}$ \\
\hline $\begin{array}{l}\text { Total } \\
\text { academic } \\
\text { staff* }\end{array}$ & 201,380 at 1 December 2015 & 30 \\
\hline Gender* & $45 \%$ female & $50 \%$ female \\
\hline $\begin{array}{l}\text { Academic } \\
\text { employment } \\
\text { function* }\end{array}$ & $\begin{array}{l}49 \% \text {, or } 98,620 \text {, of academic staff } \\
\text { on } 1 \text { December } 2015 \text { were } \\
\text { employed on contracts described as } \\
\text { having a teaching and research } \\
\text { function, } 26 \% \text {, or } 52,590 \text {, had an } \\
\text { academic employment function } \\
\text { described as teaching only. }\end{array}$ & $\begin{array}{l}100 \% \text { teaching and research } \\
\text { function. }\end{array}$ \\
\hline $\begin{array}{l}\text { Terms of } \\
\text { employment* }\end{array}$ & $\begin{array}{l}66 \% \text {, or } 132,070 \text {, of academic staff } \\
\text { were employed on open-ended or } \\
\text { permanent contracts in } 2015 / 16 \text { and } \\
34 \% \text { were employed on fixed term } \\
\text { contracts. }\end{array}$ & $\begin{array}{l}87 \% \text { (26) of participants were } \\
\text { employed on open-ended or } \\
\text { permanent contracts and } 13 \% \text { (4) } \\
\text { were employed on fixed term } \\
\text { contracts. }\end{array}$ \\
\hline $\begin{array}{l}\text { Contract } \\
\text { level* }\end{array}$ & $\begin{array}{l}87 \% \text { or } 175,245 \text { on grade other } \\
\text { than professor or senior academic }\end{array}$ & $\begin{array}{l}90 \%(27) \text { on grade other than } \\
\text { professor or senior academic }\end{array}$ \\
\hline Nationality* & $\begin{array}{l}\text { Of those academic staff with } \\
\text { known nationality, } 17 \% \text {, or } 33,735 \text {, } \\
\text { had an EU (excluding the UK) } \\
\text { nationality, and } 12 \% \text { had a non-EU } \\
\text { nationality. }\end{array}$ & $\begin{array}{l}\text { Of the } 29 \text { participants with known } \\
\text { nationality } 13 \% \text { had an EU } \\
\text { (excluding the UK) nationality, and } \\
30 \% \text { had a non-EU nationality. }\end{array}$ \\
\hline $\begin{array}{l}\text { Academic } \\
\text { teaching } \\
\text { qualification** }\end{array}$ & $\begin{array}{l}\text { In England, } 47 \% \text { of academic staff } \\
\text { held a teaching qualification, } 30 \% \\
\text { held no teaching qualification (not } \\
\text { known, } 22 \% \text { ) }\end{array}$ & $\begin{array}{l}80 \% \text { of participants held a teaching } \\
\text { qualification [i.e. had completed at } \\
\text { least one module of an accredited } \\
\text { qualification], } 10 \% \text { held no } \\
\text { teaching qualification (not known, } \\
10 \% \text { ) }\end{array}$ \\
\hline$*$ & \multicolumn{2}{|c|}{$\begin{array}{l}\text { 2015-16 UK figures from HESA (2017) Staff at higher education } \\
\text { providers in the United Kingdom 2015/16. } \\
\text { https://www.hesa.ac.uk/news/19-01-2017/sfr243-staff [accessed } 9 \text { May } \\
\text { 2017] }\end{array}$} \\
\hline$* *$ & \multicolumn{2}{|c|}{$\begin{array}{l}\text { The latest available UK figures published by HEFCE (the Higher } \\
\text { Education Funding Council for England) are from 2014-15, see } \\
\text { http://www.hefce.ac.uk/data/Year/2016/tqual/Title,111657,en.html\#alldo } \\
\text { wnloads [accessed 9 May 2017] }\end{array}$} \\
\hline
\end{tabular}


One important variable missing from Table 1, however, is the holding of a doctorate, which could provide a proxy for understanding the academic vocation. Although not yet publicly available, UK academic staff qualification data is collected, and the proportion of those holding a doctorate is understood to have grown from around 46 per cent in 2010 to 54 per cent in 2016, with much variation between HEIs (Baker, 2018). Only four participants out of thirty held a doctorate at the time of interview, while a further five enrolled on doctoral studies during their induction period.

Of the thirty interviewees, five left shortly after interview and within three years of appointment. Hence, although our sample is small, this leaver rate is significantly higher than the 7.9 per cent annual academic leaver rate in the UK academic workforce given by UCEA (2017), and may be a result of participants' marketability due to their extensive professional expertise.

\section{Interviews and the data theming process}

Semi-structured, face-to-face interviews were conducted. All interviews lasted between 30 minutes and two hours, and were transcribed verbatim for thematic analysis (Braun \& Clarke, 2006). Interviews were conducted as conversations focusing on five key areas: The move from professional practice to academia; challenges encountered; positive experiences; opportunities; and institutional support. As former professional practitioners ourselves, our interpretation of the data was necessarily reflexive (Kim, 2015), in that we acknowledged aspects of the academic and non-academic employment processes that we had experienced ourselves or encountered amongst colleagues. Based on the narratives centred on the five key areas, four overarching themes emerged relevant to the focus of this paper, namely: reasons for transition into academia; initial experiences; managing expectations; and perceived institutional support. These themes are explored in the following section.

\section{Analysis}

\section{Reasons for transition into academia}

Leaving professional practice was a significant career move for our participants. As Boden, Epstein, and Kenway (2005) suggest, motivations for entering academia via the 'professional route' are varied. Our analysis suggests that, for our interviewees, these factors fall into three sub-themes: contributing to one's discipline, retaining a 
practitioner's identity, and academia as a bolt-hole.

\section{Contributing to one's discipline}

Looking back to their original motivations for becoming academics, almost all our interviewees indicated that they had felt they could share their professional insights with students. For example, Lisle (I2) said 'I realised I had a lot to give the students from my experience ... it is a mutually beneficial sort of relationship and activity'. Participants also often referred to giving something back to their discipline; or improving the education of new graduates, and making use of their accumulated expertise. Bonnie (I1) summed up a common feeling, 'I thought my practice could feed teaching and that my teaching could make sure that I was up-to-date on the latest research and inform my practice. I thought it was going to be quite symbiotic, that the two would mutually benefit'. From their outsiders' perspective, our interviewees judged higher education as in need of their authentic knowledge and expertise: the job vacancy they had applied for confirmed this, and many had witnessed shortcomings in junior colleagues that they felt evidenced the need for better university teaching in their particular discipline. Some participants expressed the notion that their repayment of disciplinary debts was preordained: 'I knew when I first went into nursing [that] one day I wanted to be [an educator/lecturer] ... it kind of felt destined' (Jem, I1); 'I don't know whether I chose it or if it chose me' (Elena, I1).

\section{Retaining a practitioner's identity}

For many interviewees, there was an expectation that, in becoming an academic, they would be able to focus on practice. For example, Lisle (I2) who had sixteen years professional experience, saw academia as an alternative to a move into management. However, few participants appreciated the diversity of the academic role nor the effort such role-accumulation (Kinman, 2016) would entail.

There was a feeling that practitioners enriched the discipline. Steve (I3) said, 'the best teachers for me have been the ones that have been able to say "well when I was working"'. Some of our participants indicated that they had deliberately chosen this career move despite its perceived accompanying financial penalties: 'Now is the time to start thinking about moving into academia before it is too late, before I get stuck earning a very high salary that would be very difficult to leave behind' (Elizabeth, I4). 
None of our interviewees suggested that they had originally perceived an opportunity to progress into academic management. On the contrary, almost all expressed how much they had looked forward to continue practicing their discipline. However, at least one has now opted for a course management role as a way of reducing the stress encountered as a lecturer (Kinman, 2016).

\section{Academia as a bolt-hole}

The 'bolt-hole' motivation was also prevalent in that academia was seen as having attributes their profession lacked. Steve (I3) explained HE's appeal:

I was working at one of these top firms ... [and] to be brutally honest it was driven by looking for something where I could use my [professional knowledge], using my brain, where I would be stimulated and that had some flexibility in terms of childcare.

Anne (I5) had been a successful self-employed public relations professional, and saw academia as an opportunity for self-development:

The opportunity for personal accomplishment is one of my biggest drivers. I get massive support to start my $\mathrm{PhD}$ and I get to go to things. As a self-employed professional, you don't always get these opportunities.

For participants with this motivation, academia is seen as 'other' - a different kind of employer from those in their own profession, perhaps offering more flexible hours, longer holidays, less competitive working conditions (Boden, Epstein, \& Kenway, 2005). Hence there is a risk that failure to fulfil such expectations would lead to the recruit later rejecting $\mathrm{HE}$.

No matter what their motivations, our participants all remembered the enthusiasms that drove them at the start. They were 'delighted', 'absolutely stunned' to be offered the job; and, at least at first, they 'really enjoyed', 'loved' teaching.

\section{Initial experiences of transition into academia}

Induction processes varied within and between the five institutions. Our participants arrived, expecting a staged process to introduce them to their new working environment. For example, 'it was very difficult. I was expecting a bit more support from the University. I thought that there would be something a bit more structured in place for new starters...' (Maxwell, I1). Similarly, Angela (I3) said '... I expected it to 
be more structured initially but that is, as I say, because of my previous working environment where everything is kind of like that. You have a week of induction and everything is planned'. Ready to be proactive, and take a share of responsibility for their initial induction, the most common experience was of feeling abandoned. For example, Roger (I1) 'I think I was expecting for somebody to come and give me a roadmap of all of the things that I needed to know and do ... nothing happened. Nobody ever showed me anything'. We have encountered individuals whose initial experiences of an HEI were so demotivating as to cause them to leave within the first weeks of appointment. Like Gourlay's subject, they expressed 'a feeling of loss and disorientation resulting from a perception of lowered status, and related lack of competence, knowledge and expertise' (p. 592).

By contrast, some participants attended an initial, formal induction week. Although this was found rather overwhelming at the time, the longer term benefits of this training were noted:

... It's not very clear at that time to see what is the purpose of this training, how useful it is, or was it just a ticking box exercise? But when I look back, I think it is. I started with three other [peers], and we all felt the same way. It was extremely helpful for us to start working here with one week induction. With all the training that equips us with all the knowledge and skills we need to use. (Amy, I2)

As Mullins (2005, p. 816) suggests, 'the first impressions of an organisation and its managers are seldom forgotten'. Some participants used a lack of welcome to illustrate why they had felt undervalued from the start: 'I turned up on the first day and [although] I was put in with [a colleague], which was great, they didn't know where I was going when I arrived' (Maxwell, I1).

On the whole, our participants' initial induction experience resonates with the recent international literature reviewed, and suggests that, still 'some had virtually to induct themselves' (Knight, 2002, p. 39). Several participants used their interviews to offer suggestions for the improvement of the initial induction process:

There could be a DIY Induction where you go through slides or lectures ... But there just isn't anything like that. I think they are missing a trick ... it would just help you to settle I think. It wouldn't take that long or that much to set up. Because there was nothing of that (John, I3)

The HEIs' documented induction procedures may already contain many of their suggestions, however, our interviewees had either not encountered them in practice, or 
had found them unsatisfactorily implemented. A similar mismatch between intended and experienced induction is noted by Staniforth and Harland (2006).

\section{Managing expectations}

Price, Coffey, and Nethery (2015, p. 695) posit from their study of early career researchers in Australia that ' $[\mathrm{w}]$ hat is clear is that for many of those who choose academia, establishing oneself requires years of challenging, and sometimes heartbreaking, effort'. This was not what our interviewees expected. Samantha (I5) compared her induction experience with her former professional induction, saying ' $\mathrm{You}$ had your hand held a little bit but [it's] very different here. I had never done any teaching. I came in still not knowing what I was doing and not being offered any support and not being provided with a mentor'. Like Wilson's (2013) lecturers, our interviewees had arrived as 'confident professionals in their subject area' (p. 117), but their initial experiences tended not to help them feel confident as academics. For some, such as Joan (I5), this approach had led to low self-esteem and a lack of self-belief as a university teacher. Newer academics will, not unreasonably, expect their line manager to play a key role in their induction and organisational socialisation (Staniforth \& Harland, 2006). Like several of our participants, Ssempebwa, Teferra and Bakkabulindi found that new recruits felt they had been left to 'swim or sink' (2016, p. 1854) rather than receive the expected induction support. Two different perceptions of using colleagues to fill the management gap were noted; firstly by Ray (I4) who was interviewed while working his notice:

I mean, I pestered [a colleague] for weeks and weeks ... [I asked] for more course related assistance but they are all busy ... and it is unnecessary pressure on everybody when a lot of the questions I was asking, they weren't difficult complicated questions, they could have been addressed quite simply ... you know, if they don't want to run sessions every week, [in] an online induction.

Ashley, from the same institution had a more positive experience:

I think I settled quite quickly. I had no choice! ... I was lucky also because my office, we had offices then, was next to [a colleague] ... she was very helpful as well. She wasn't officially my mentor or anything but I worked very closely ... she was excellent in helping me to settle in and sort things out.

Whereas trained mentors can 'directly reduce newcomer turnover' (Allen, 2006, p. 253), reliance on colleagues for ad hoc advice and support can be problematic. These colleagues were not designated mentors with this role as part of their job description. 
Hence there would be issues regarding the reliability of the information given, and the time commitment on both sides of these unofficial mentoring relationships.

Under the theme of managing expectations, the issue of time pressures occurs frequently. Time pressure is associated with unsatisfactory induction where it arises from a lack of training or support. For example, Johnny (I5) who has now left his HEI, said 'When I started, I was told that I was in charge of a module and that it was beginning in two weeks. So I had to get that together, continuingly writing as I was delivering it.' This quotation also reflects the key concern raised by many interviewees: their allocation of responsibilities for which they did not feel ready. These responsibilities covered all aspects of academic practice from teaching to research, from module or programme leadership to the pastoral care of students. For some, the issue centred on a lack of training or experience, for others, a lack of a sense of workload priorities (Smith, 2017). For several interviewees, what they saw as unreasonable expectations from their HEI was driving them to resign or to consider resigning. David (I5), for example, was unambiguous:

How do I cope? I leave.

\section{Perceived institutional support}

Amy (I2), who had briefly worked in another HEI, recognised the importance of a structured induction. 'Before, you just quickly grab someone from somewhere [saying] "can you quickly show me?" or just do the necessary part to get by ... here is the first time I feel I was provided with everything I needed to do the job'.

As observed by Knight (2002), academic departments vary greatly in their support of individual recruits, but often it is busy colleagues who are relied on day-today. This reliance on colleagues rather than one's manager is well-evidenced in the interviews. Where collegial support was available, the academic life could be viewed more positively:

\footnotetext{
'I was effectively expecting to learn how to do the job ... and I had a lot of support to do this. ... it is basically seeing an academic year through. Just to understand how a university works ... I am getting there.' (Francesca, I4)
}

Allen (2006) suggests that 'perceived organisational support' is essential in order to retain staff, and it is this perception that some of our participants identified as missing from their induction in contrast to their expectations. For example, Jessica (I5) 
remarked that 'we were very understaffed so my mentor had no time to mentor'. This demonstrates a discrepancy between induction policy and its implementation (Staniforth \& Harland, 2006). Since recruits construct a psychological contract which is based on an expectation of reciprocity between themselves and their employer, failure to manage these expectations can lead to dissatisfaction which may, in turn, cause an individual to leave their new post, or to remain but, in extreme cases, 'burn out', displaying exhaustion, cynicism and inefficiency (Maslach, Schaufeli, \& Leiter, 2001). Hence the importance of ensuring that induction processes are properly implemented.

\section{Implications and recommendations}

The best career move ever. Love it (Elena, I1).

How can HEIs foster and retain such enthusiasm? There appears to be a lack of connection between the imperatives that drive practitioner recruitment into the academy and their management once recruited. We recognise that a new recruit may leave no matter how good their induction, but our study participants illustrate the risk in recruiting 'non-standard' yet worthwhile individuals. Practice-based academics facilitate the employability agenda (Boden, Epstein, \& Kenway, 2005) but may lack academic capital, find the transition a struggle, and be tempted to return to the comparative safety of their former life. The trend to make doctoral qualification (or study) compulsory for new academics (Baker, 2018) has recently been followed by four of our five institutions - the fifth considers a doctorate desirable but recognises that recent practice-based expertise may be equivalent in certain disciplines. The effects of both policies requires future research.

We frame our recommendations with Bartunek and Rynes (2014) notion of tensions between practitioners and academics. Firstly, rigour and relevance. To a practitioner, induction processes which are unsatisfactorily implemented lack rigour; while induction that focuses on compliance and regulation but ignores day-to-day practice, lacks relevance. Nonetheless, practice-based academics with support expectations established in non-HE work environments, may have higher support needs than induction policies prescribe (Logan, Gallimore, \& Jordan, 2015). Our recommendation is that HEIs review the efficacy of academic induction processes, and ensure they are fit for purpose: not just for practitioners, but for all academic staff. 
Secondly, timelines. Practitioners' perception of time is much tighter than academics'. While some recruits might tolerate arriving on campus unwelcomed or unexpected, a practitioner becomes more appalled with each hour that passes. Ensuring the manager contacts the new recruit prior to arrival, that their workstation is readied, their system accesses are pre-loaded, are all commonplace in the world outside HE. None of our participants encountered any of this, hence the job of retaining them was made all the more difficult. Our recommendation is that HEIs ensure that all new recruits feel valued, even before arrival.

Thirdly, communication. Practitioners expect open and active communication between their line-manager, themselves, and other key personnel. This is achievable, but requires academic leaders to prioritise effective communication with their team members. Our recommendation is that HEIs model and reward team-communication best practice.

Finally, thinking/logics. Academia rewards the selfish researcher (Smith, 2017). Only three of our practitioners understood the importance of research compared with teaching or why colleagues worked behind closed doors. The standard induction activities would assist here: mentoring, coaching, clear expression of priorities by their line manager, early scheduled performance review. HEIs might also like to consider induction which supports individuals' specific cultural differences: in this case, those new to the academic profession.

Although academic staff retention rarely acts as a key performance indicator in this sector (Hazelkorn, 2015), the cost of recruitment, and the potential disruption caused by voluntary resignations should be a matter of concern to HEIs (O'Meara, Bennett, \& Neihaus, 2016; Schloss et al., 2009). It has been noted in other sectors (Allen, 2006), that unsatisfactory staff induction can be causally linked to poor retention. Although the outside experience that enabled our participants to jump into a university role may have made them demanding inductees, we do not argue that such individuals require specialised induction in order to promote retention. Rather, we contend that everyone requires individualised induction.

\section{Conclusion}

Academic staff turnover has an impact on the individual (Watanabe, \& Falci, 2016), their colleagues (O’Meara, Lounder, \& Campbell, 2014), and departmental budgets. 
Ketchen Jr. et al., (2017) recommend the strategic retention of staff through individual interventions and organisation-wide systems. We identify the induction of academic staff as a prime candidate for such interventions and further research.

Academic life is challenging. Weber (1948 [1919]) suggests that the strong will survive, however, in the context of practice-based academics, this strikes us as a wasteful and costly employment strategy. Our overall recommendation is that HEIs' academic staff induction becomes a long-term process of mutual benefit rather than a series of training commitments and approval hurdles the employee alone must satisfy. Treating the recruit as an individual; supporting them according to their specific needs; and ensuring clarity of expectations between the individual and their manager, all appear to be key to the perception of HEI support. A policy shift is required for HEIs to address the individual induction needs and expectations of academic recruits in order to maximise their retention, and, potentially, gain league table recognition.

\section{Acknowledgements}

We would like to thank all those colleagues who participated in this research. We would also like to thank our peer reviewers for detailed and valuable feedback.

\section{References}

Allen, D. G. (2006). Do organizational socialization tactics influence newcomer embeddedness and turnover? Journal of Management, 32 (2), 237-256. Doi:10.1177/0149206305280103

Australian Government (2016) Department of Education and Training, Staff Data. Available from https://www.education.gov.au/staff-data. [Accessed 9 May 2017]

Baker, S. (2018, March 8). Mandatory PhD policies lead to boom in academics with doctorates. Times Higher Education. Retrieved from https://www.timeshighereducation.com/news/mandatory-phd-policies-leadboom-academics-doctorates

Bentley, P. J., Coates, H., Dobson, I. R., Goedegebuure, L., \& Meek, V. L. (2013). Factors associated with job satisfaction amongst Australian university academics and future workforce implications. In P. Bentley, H. Coates, I. Dobson, L. Goedegebuure, \& V. L. Meek (Eds.), Job satisfaction around the academic world (pp. 29-53). Dordrecht, Netherlands: Springer Netherlands. 
Billot, J. \& King, V. (2017). The Missing Measure? Academic identity and the induction process. Higher Education Research \& Development, 36(3), 612-624. Doi:10.1080/07294360.2017.1288705

Boden, R., Epstein, D. \& Kenway, J. (2005). Building your academic career: Theory, practice and reform. London: Sage.

Braun, V. \& Clarke, V. (2006). Using thematic analysis in psychology. Qualitative Research in Psychology, 3(2), 77-101. Doi:10.1191/1478088706qp063oa

Bucklin, B. A., Valley, M., Welch, C., Tran, Z. V., \& Lowenstein, S. R. (2014). Predictors of early faculty attrition at one academic medical center. $B M C$ Medical Education, 14(1), 27. Doi:10.1186/1472-6920-14-27

Denscombe, M. (2014), The good research guide: For small-scale social research projects (5th edn.). Maidenhead, UK: Open University Press.

Dominguez-Whitehead, Y. \& Moosa, M. (2014). New Academics in the South African Research-oriented Academy: A Critical Review of Challenges and Support Structures. Alternation Special Edition, 12, 260 - 282

Gourlay, L. (2011). 'I'd landed on the moon': a new lecturer leaves the academy. Teaching in Higher Education, 16, 591-601. Doi:10.1080/13562517.2011.605548

Hazelkorn, E. (2015). Rankings and the reshaping of higher education: The battle for world-class excellence (2nd. Ed.). Basingstoke, UK: Palgrave

Higher Education Funding Council for England [HEFCE] (2015). Academic teaching qualifications statement. Available from http://www.hefce.ac.uk/lt/wider/atq/ [Accessed 13 May 2018]

Higher Education Statistics Agency [HESA] (2017). Staff at higher education providers in the United Kingdom 2015/16. Available from https://www.hesa.ac.uk/dataand-analysis/publications/staff-2015-16 [Accessed 9 May 2017]

Ketchen Jr., D. J., Crook, T. R., Todd, S. Y., Combs, J. G. \& Woehr D. J. (2017). Managing human capital: A meta-analysis of links among human resource practices and systems, human capital, and performance. In M. A. Hitt, S. E. Jackson, S. Carmona, L. Bierman, C E. Shalley, \& M. Wright (Eds.), The Oxford Handbook of Strategy Implementation (pp. 283-310). New York: Oxford University Press 
Kim, J. -H. (2015). Understanding narrative inquiry: The crafting and analysis of stories as research. Thousand Oaks: Sage.

Kinman, G. (2016). Effort-reward imbalance and overcommitment in UK academics: implications for mental health, satisfaction and retention. Journal of Higher Education Policy and Management, 38 (5), 504-518.

Doi:10.1080/1360080X.2016.1181884

Knight, P. (2002). Being a Teacher in Higher Education. Buckingham, UK: SRHE and Open University Press

Logan, P.A., Gallimore, D., \& Jordan, S. (2015) Transition from clinician to academic: an interview study of the experiences of UK and Australian Registered Nurses. Journal of Advanced Nursing, 72 (3), 593-604, doi:10.1111/jan.12848

Maslach, C., Schaufeli, W. B., \& Leiter, M. P. (2001). Job burnout. Annual Review of Psychology, 52 (1), 397-422.

Maxwell, G. \& Farquharson, L. (2008). Senior managers' perceptions of the practice of human resource management. Employee Relations, 30(3), 304-322, doi:10.1108/01425450810866550

Meizlish, D. S., Wright, M. C., Howard, J., \& Kaplan, M. L. (2017). Measuring the impact of a new faculty program using institutional data. International Journal for Academic Development, doi:10.1080/1360144X.2017.1364644

Mullins, L. J. (2005). Management and organisation behaviour (7th edn.). Harlow: Pearson Education.

O’Meara, K., Bennett, J. C., \& Neihaus, E. (2016). Left Unsaid: The role of work expectations and psychological contracts in faculty careers and departure. The Review of Higher Education, 39(2), 269-297. Doi:10.1353/rhe.2016.0007

O’Meara, K.A., Lounder, A., \& Campbell, C.M. (2014). To heaven or hell: Sensemaking about why faculty leave. Journal of Higher Education, 85(5), 603632.

Price, E., Coffey, B., \& Nethery, A. (2015). An early career academic network: What worked and what didn't. Journal of Further and Higher Education, 39(5), 680698. Doi:10.1080/0309877X.2014.971106

Robyn, A., \& Du Preez, R. (2013). Intention to quit amongst Generation Y academics in higher education. SA Journal of Industrial Psychology/SA Tydskrif vir 
Bedryfsielkunde, 39(1), Art. \#1106, 14 pages. http://dx.doi.org/10.4102/ sajip.v39i1.1106

Saltmarsh, S. \& Swirski, T. (2010). 'Pawns and prawns': international academics' observations on their transition to working in an Australian university. Journal of Higher Education Policy and Management, 32 (3), 291-301. Doi:10.1080/13600801003743505

Schloss, E.P., Flanagan, D. M., Culler, C. L., \& Wright, A. L. (2009). Some hidden costs of faculty turnover in clinical departments in one academic medical center. Academic Medicine, 84(1), 32-36. Doi:10.1097/ACM.0b013e3181906dff

Smith, J. (2010). Forging identities: The experiences of probationary lecturers in the UK. Studies in Higher Education, 35(5), 577-591. Doi:10.1080/03075070903216650

Smith, J. (2017). Target-setting, early-career academic identities and the measurement culture of UK higher education. Higher Education Research \& Development, 36 (3), 597-611, DOI: 10.1080/07294360.2017.1288708

Ssempebwa, J., Teferra, D. \& Bakkabulindi, F. E. K. (2016). 'Swim or sink': State of induction in the deployment of early career academics into teaching at Makerere University. Studies in Higher Education, 41, 1854-1868.

Doi:10.1080/03075079.2016.1221649

Staniforth, D. \& Harland, T. (2006). Contrasting views of induction: The experiences of new academic staff and their heads of department. Active Learning in Higher Education, 7(2), 185-196 https://doi.org/10.1177/1469787406064753

Universities and Colleges Employers Association [UCEA] (2017). Higher Education Workforce Survey 2017. Available from http://www.ucea.ac.uk/en/empres/rs/employ/hews.cfm [Accessed 31 July 2017]

University of Sheffield (2017). News, 23 February 2017: University of Sheffield named among best places to work in UK for second year in a row. https://www.sheffield.ac.uk/news/nr/best-companies-to-work-for-ukuniversities-1.683809 [Accessed 17 October 2017].

Walker, P. (2015). The globalisation of higher education and the sojourner academic: Insights into challenges experienced by newly appointed international academic staff in a UK university. Journal of Research in International Education, 14(1), 61-74. 
Watanabe, M., \& Falci, C. D. (2016). A demands and resources approach to understanding faculty turnover intentions due to work-family balance. Journal of Family Issues, 37(3), 393-415. doi: 10.1177/0192513X14530972

Weber, M. (1948 [1919]). Science as a vocation [Wissenschaft als Beruf]. (Trans. H.H. Gerth and C. Wright Mills) In From Max Weber: Essays in Sociology (2nd ed.), (pp. 129-156). London: Routledge

Welch, A. (2016). Audit culture and academic production. Higher Education Policy, 29 511-538. doi:10.1057/s41307-016-0022-8

Wilson, L. (2013). Welcome on board: Designing support interventions to meet the needs of new part-time lecturers. In F. Beaton \& A. Gilbert (Eds.), Developing effective part-time teachers in higher education: New approaches to professional development (pp. 117-133). (SEDA Series) Abingdon, UK:

Routledge.

Yan, G., Yue, Y. \& Niu, M. (2015). An empirical study of faculty mobility in China. Higher Education, 69, 527-546. doi:10.1007/s10734-014-9789-y

\section{Disclosure statement}

None of the authors has any financial interest or benefit arising from the direct applications of their research. 